\title{
EKSISTENSI KESENIAN BESUTAN SEBAGAI IDENTITAS BUDAYA KABUPATEN JOMBANG
}

\author{
Lailil Nadhifatul Muazaroh $^{1^{\star}}$, I Nyoman Ruja ${ }^{1}$, Neni Wahyuningtyas ${ }^{1}$ \\ ${ }^{1}$ Universitas Negeri Malang, Indonesia \\ *e-mail: laililnadhifa06@gmail.com
}

\begin{abstract}
Abstrak
Penelitian ini bertujuan untuk menganalisis eksistensi kesenian Besutan di Kabupaten Jombang. Penelitian ini menggunakan metode penelitian kualitatif deskriptif. Teknik pengumpulan data yang digunakan dalam penelitian ini berupa pengamatan, wawancara, dokumentasi, dan divalidasi menggunakan triangulasi. Data yang telah berhasil dikumpulkan kemudian dianalisis menggunakan konsep analisis data model interaktif. Hasil penelitian menyatakan bahwa kesenian besutan merupakan kesenian tradisional yang muncul pada tahun 1907. Besutan pertama kali dibawakan oleh Pak Santik dengan cara amen atau berkeliling dari rumah ke rumah dengan menghias dirinya dengan cara mencoretcoret wajahnya. Namun sekarang kesenian Besutan menjadi kesenian yang jarang ditemui, oleh karena itu pemerintah dan pelaku seni melakukan berbagai upaya agar kesenian Besutan menjadi kesenian yang tetap ada dan dinikmati oleh semua masyarakat terutama masyarakat Kabupaten Jombang.
\end{abstract}

Kata kunci: Eksistensi; Kesenian Besutan; Pelestarian Seni

\begin{abstract}
This research aims to analyze the existence of Besutan art in the Jombang Regency. This study uses descriptive qualitative research methods. The data collection techniques used in this study are observation, interview, documentation, and validated using triangulation. The data that has been successfully collected is then analyzed using Miles and Huberman analysis concepts. The study results stated that the art of besutan is a traditional art that appeared in 1907. Besutan was first performed by Mr. Santik by amen or traveling from house to house by decorating himself by scribbling his face. Nevertheless, now besutan art becomes a rare art. Therefore the government and art actors make various efforts to make besutan art become an art that remains and enjoyed by all communities, especially the people of Jombang Regency.
\end{abstract}

Keywords: Existence; Art of Besutan; Art Preservation

This is an open access article under the $\underline{C C B Y-S A}$ license.

Copyright (0 2021 by Author. Published by Universitas Pendidikan Ganesha.

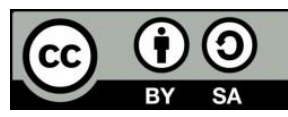

\section{PENDAHULUAN}

Indonesia merupakan negara multikultural yang memiliki beragam budaya. Keanekaragaman budaya yang dimiliki Indonesia menjadi ciri khas dari setiap daerah. Keanekaragaman tersebut terlihat dari perbedaan bahasa, etnis dan keyakinan agama (Raharjo, 2006). Adat istiadat, agama, seni, budaya, dan bahasa yang beraneka ragam berkembang dan menjadi kebudayaan nasional dan kebudayaan daerah di Indonesia. Keanekaragaman budaya di Indonesia menjadi penopang pelestarian budaya di Indonesia.

Kebudayaan daerah di Indonesia menjadi identitas budaya daerah tersebut. Kesenian Besutan adalah salah satu kebudayaan daerah Kabupaten Jombang dan sekaligus menjadi identitas budaya
Kabupaten Jombang. Kesenian Besutan merupakan kesenian dari hasil akulturasi dua budaya budaya Jawa yang besar yakni budaya Arek (Suroboyoan) dan budaya Mataraman (Pamungkas, 2016). Akulturasi dua budaya ini terletak pada dialek Besutan dimana dialek tersebut hasil dari percampuran dialek Suroboyoan (daerah Surabaya) dan dialek Mataraman (daerah Ngawi-Kediri) menjadi dialek Jombangan. Hal ini dikarenakan wilayah Jombang yang berbatasan dengan wilayah Ngawi dan Kediri dan Jombang sendiri merupakan wilayah eks-karesidenan Surabaya.

Besutan merupakan seni pertunjukan teater asli Kabupaten Jombang yang berkembang dari kesenian Lerok dan menjadi cikal bakal kesenian Ludruk. Awalnya Besutan hanya berasal dari spontanitas masyarakat, yang kemudian 
dihayati oleh masyarakat di lingkungannya, dan berkembang sesuai dengan perkembangan lingkungannya. Besutan merupakan sebuah drama tradisional yang menggambarkan kehidupan sehari-hari dari potret kehidupan masyarakat Jombang. Besutan banyak menggambarkan tentang keadaan sosial yang terjadi dalam masyarakat. Kesenian Besutan ini dipercaya masyarakat mengandung pesanpesan sindiran yang saat itu ditujukan kepada pemerintah kolonial maupun keadaan ekonomi yang tidak baik (Damayanti, 2007). Besutan saat itu menjadi sarana penyampaian aspirasi masyarakat untuk pemerintah dan kebijakannya. Dengan lawakan jenaka, penonton di bawa untuk melihat kejadian yang ada dalam masyarakat dan masalahmasalah yang berkembang di masyarakat yang belum teratasi. Kesenian Besutan saat itu juga memiliki fungsi lain yaitu sebagai sarana ritual atau religi, sarana pendidikan, dan media hiburan dan sebagai sarana penyalur informasi yang efektif untuk menyampaikan program dan kebijakan pemerintah kepada masyarakat. Inilah alasan kenapa kesenian Besutan sangat diinginkan untuk kembali aktif (Anggita, 2013).

Kesenian Besutan menjadi ikon budaya Kabupaten Jombang maka seharusnya kesenian Besutan harus tetap ada namun saat ini kesenian Besutan tengah mengalami permasalahan yang sama dengan kesenian atau kebudayaan daerah lain yang ada di Indonesia yaitu kesenian ini mulai punah akibat tidak adanya generasi penerus dan tergerus oleh arus perkembangan zaman yang semakin modern (Rifanti, 2017).

Proses regenerasi yang tidak berjalan dalam hal pelaku seni di Jombang menjadi salah satu penyebab kurangnya minat pada kesenian tradisional khususnya Besutan (Firmansyah, 2015). Pemerintah Kabupaten Jombang menginginkan kembalinya kesenian Besutan untuk dinikmati kembali oleh masyarakat Kabupaten Jombang.

Tak hanya kesenian Besutan beberapa kesenian lain juga terancam keberadaannya karena pengaruh globalisasi. Beberapa diantaranya adalah kesenian Gambang Semarang. Gambang Semarang adalah kesenian rakyat yang menjadi kesenian elit menjadikan masyarakat tidak begitu mengenal kesenian ini. Beberpa masyarakat masih menginginkan keberadaan kesenian ini sehingga pemerintah berupaya agar kesenian ini tidak punah (Septiyan, 2016).

Berdasarkan pertimbangan dari penelitian di atas maka peneliti tertarik untuk mengkaji tentang "Eksistensi Kesenian Besutan sebagai Identitas Budaya Kabupaten Jombang". Alasan peneliti melakukan penelitian ini adalah keberadaan kesenian Besutan yang sudah jarang ditemui di era saat ini. Di mana seharusnya kesenian Besutan ini menjadi identitas budaya masyarakat Jombang yang harus dilestarikan. Mulai dari mengkaji sejarah kesenian Besutan, bentuk penyajian Kesenian Besutan, upaya yang dilakukan pemerintah dan pelaku seni dalam mempertahankan kesenian Besutan, serta pertimbangan mengundang kesenian Besutan.

\section{METODE}

$\begin{array}{ccc}\text { Penelitian } & \text { ini } & \text { menggunakan } \\ \text { pendekatan } & \text { penelitian } & \text { kualitatif. }\end{array}$ Pendekatan kualitatif memusatkan pada prinsip umum yang mendasari perwujudan sebuah makna dari gejala sosial di masyarakat (Bungin, 2017). Terkait dengan kajian tersebut penelitian ini bertujuan untuk menggambarkan tentang bagaimana eksistensi kesenian Besutan yang ada di Kabupaten Jombang. Jenis penelitian ini menggunakan penelitian fenomenologi. Fenomenologi merupakan sudut pandang yang fokus terhadap pengalamanpengalaman individu dan interpretasi dunia. Femonenologi juga dimaknai sebagai metode dalam mencari makna-makna psikologis yang membentuk gejala melalui investigasi dan analisis contoh-contoh gejala yang dialami oleh partisipan (Mujib, 2015). Penelitian fenomenologi tidak memberikan perlakuan manipulasi atau pengubahan pada subjek yang diteliti, melainkan menggambarkan suatu kondisi yang apa adanya. Satu-satunya perlakuan yang diberikan hanyalah penelitian itu sendiri, yang dilakukan melalui observasi, wawancara, dan dokumentasi (Bungin, 2017). Pilihan terhadap jenis penelitian ini, dikarenakan fenomena yang akan diteliti merupakan suatu kajian yang unik, serta membutuhkan pengkajian yang mendalam. Penelitian ini digunakan untuk menggambarkan kesenian Besutan mulai dari sejarah kesenian Besutan di Kabupaten Jombang, penyajian pertunjukan seni Besutan di Kabupaten Jombang, upaya pelestarian kesenian 
Besutan di Kabupaten Jombang hingga pendapat pengundang terhadap kesenian Besutan dan alasan mereka mengundang kesenian Besutan.

Sumber data pada penelitian ini dalam penelitian ini terdiri atas data primer dan data sekunder. Data primer diperoleh dari hasil penelitian langsung di lapangan melalui wawancara dan observasi di lokasi yang sudah ditentukan, yakni di Sanggar Komunitas Tombo Ati Desa Sengon Kecamatan Jombang Kabupaten Jombang. Informan dalam penelitian ini dipilih atas kesesuaian tema yang diambil, terdiri dari informan kunci dan informan pendukung. Informan kunci dalam penelitian ini yaitu sejarawan dan pengundang di Kabupaten Jombang. Sedangkan informan pendukung dalam penelitian ini yaitu ketua dan pelaku seni di Sanggar Komunitas Tombo Ati, serta pemerintah daerah Kabupaten Jombang. Sumber data sekunder diperoleh dari studi pustaka yang berupa beberapa sumber tertulis. seperti buku, majalah ilmiah, arsip, dokumen pribadi, maupun dokumen resmi.

Lokasi penelitian disesuaikan dengan asal kesenian Besutan yang berasal dari Kabupaten Jombang lebih tepatnya dilakukan di sanggar Komunitas Tombo Ati yang bertempat di desa Sengon Kecamatan Jombang Kabupaten Jombang, hal ini dikarenakan di sanggar Komunitas Tombo Ati masih melestarikan dan mementaskan kesenian Besutan. Selain itu di Sanggar Komunitas Tombo Ati ini juga terdapat banyak seniman lokal yang saling bahu membahu melestarikan kesenian Besutan.

Penelitian ini menggunakan teknik analisis data dari model interaktif Miles dan Hubermen, yang meliputi pengumpulan data, reduksi data, penyajian data, dan penarikan kesimpulan. Sedangkan teknik untuk pengecekan Keabsahan data dilakukan dengan Uji kredibilitas, dalam penelitian ini adalah menguji kepercayaan hasil temuan. Cara yang dilakukan adalah dengan melakukan triangulasi data, memperpanjang pengamatan, diskusi dengan teman sejawat (Rustanto, 2015). Cara agar hasil temuan dinyatakan kredibel adalah dengan mempertekun saat pengumpulan data dan triangulasi data. Triangulasi data adalah teknik pengumpulan data dengan cara menggabungkan data dari berbagai teknik pengumpulan dan sumber data yang telah ada (Sugiyono, 2016). Triangulasi yang digunakan dalam penelitian ini adalah triangulasi sumber dengan mengecek data yang telah diperoleh dari beberapa sumber (Rustanto, 2015). Uji transferability digunakan untuk menguji sejauh mana hasil penelitian dapat diterapkan dalam situasi lain (Rustanto, 2015). Uji ini disebut juga sebagai uji validitas eksternal karena uji ini dilakukan oleh pihak lain yang membaca laporan hasil penelitian. Sehingga dalam menulis laporan hasil penelitian harus secara rinci, jelas, sistematis, dan dapat dipercaya (Rustanto, 2015). Uji dependability dalam penelitian kualitatif dilakukan dengan melakukan audit terhadap keseluruhan proses penelitian (Sugiyono, 2016). Audit adalah pengecekan kebenaran keseluruhan proses penelitian oleh pihak luar. Sehingga dalam penelitian ini, uji dependibility dilakukan dengan melakukan pengecekan kepada auditor independen atau pembimbing (melakukan bimbingan) mulai dari tahap penentuan fokus penelitian, analisis data, hingga tahap penarikan kesimpulan. Uji conformability dalam penelitian digunakan untuk menguji keobjektifan hasil temuan. Hal ini dilakukan karena penelitian dikatakan objektif apabila hasilnya telah disepakati oleh orang banyak (Rustanto, 2015). Selain itu, jika hasil penelitian sudah sesuai dengan proses yang dilakukan, maka penelitian tersebut telah memenuhi uji confirmability.

\section{HASIL DAN PEMBAHASAN Sejarah Kesenian Besutan Di Kabupaten Jombang}

Kesenian adalah salah satu isi dari kebudayaan manusia secara umum, karena dengan berkesenian merupakan cerminan dari suatu bentuk peradaban yang tumbuh dan berkembang sesuai dengan keinginan dan cita-cita yang berpedoman kepada nilai-nilai yang berlaku dan dilakukan dalam bentuk aktivitas berkesenian (Arifninetrirosa, 2005). Kesenian lokal adalah kesenian yang diciptakan oleh masyarakat banyak yang mengandung unsur keindahan yang hasilnya menjadi milik bersama (Alwi \& dkk, 2003). Keberadaan kesenian lokal sering kali disikapi sebagai ekspresi dan identitas kultural sekaligus berbasis kearifan dan keunikan lokal suatu masyarakat (Irianto \& subandi, 2015).

Kesenian Besutan merupakan kesenian teater rakyat yang mulai berkembang di Kabupaten Jombang dengan gaya teater tutur atau lisan. 
Besutan di ketahui sebagai kesenian teater rakyat yang ada mulai tahun 1907. Pada saat itu pemain Besutan tampil dengan mencoret-coret wajahnya yang disebut Wong Lorek atau orang yang penuh dengan coretan (Damayanti, 2007). Karena adanya variasi Bahasa maka kata Lorek berubah menjadi Lerok, kata lerok diambil dari kata lira, yaitu alat musik yang berbentuk seperti kecapi (cimplung siter) yang dipetik oleh Besut sambil bersenandung mengungkapkan isi hati. Lerok merupakan kesenian yang menampilkan kesenian teater sederhana.

Besutan adalah kesenian teater yang berkembang dari kisah-kisah masyarakatnya dan terus berkembang seiring dengan perkembangan masyarakatnya. Alur cerita Besutan lahir dari spontanitas pemainnya yang di ditunjukkan dengan tubuh sebagai media utamanya. Unsur teater yang ada dalam kesenian Besutan adalah pelaku, naskah, panggung, sutradara, pakaian, perlengkapan, dan penonton (Damayanti, 2007). Besutan digunakan sebagai media penyampaian pesan perjuangan kepada masyarakat, perjuangan melawan penjajah. Cerita dalam Besutan bermaksud membawa pesan tersembunyi semacam kritik yang penuh dengan simbol-simbol yang ditujukan kepada pemerintah pada jaman itu dengan dibumbui kreatifitas seni (Indarti, 2008).

Terjadi penambahan lakon atau tokoh yang dilakukan pada kesenian Lerok ini, adanya penambahan lakon atau tokoh membuat Lerok berganti nama menjadi Besutan. Besut sendiri berarti beto maksud (membawa pesan), namun ada pula yang menyebutkan bahwa "Besut" berasal dari kata "besof" (menari) (Darmawan \& Wahyurini, 2016). Selain itu, menurut Tajuk, "Besut" artinya adalah "bebet sing bermaksud" (lilitan kain yang memiliki maksud).

Besutan pada dasarnya merupakan kelanjutan Lerok yang mendapat pengaruh dalam gaya dan pementasan dari Komedie Stamboel Jawi. Komedi Stamboel Jawi adalah kelompok drama modern yang pertama kali hadir di panggung pertunjukan Indonesia, yang berdiri di Surabaya. Pengaruh Komedie Stamboel Jawi ternyata juga sangat kuat dalam perkembangan Besutan, sehingga Besutan akhirnya mengalami perubahan besar, terutama dalam pemasukan unsur-unsur drama yang bersifat lebih modern. Misalnya dalam penokohan dan lakon yang dipentaskan (Anggita, 2013). Adapun ciri-ciri Besutan yang kemudian terdapat pada Ludruk yang selanjutnya adalah penari remo, kidungan, dan tokoh pelawak.

Besutan muncul pertama kali pada masa penjajahan Belanda dan mulai disempurnakan pada masa penjajahan Jepang (Anggita, 2013). Pada saat itu Besutan digunakan sebagai kritik sosial dan penyampaian keluhan masyarakat karena cerita yang diangkat berasal dari kehidupan sehari-hari masyarakat. Dalam pementasannya, Besutan selalu menampilkan tiga karakter/tokoh utama yang selalu ada di setiap cerita atau naskah, yaitu Besut, Man Gondo, Rusmini. Syarat untuk bisa memerankan tokoh cerita dalam Besutan adalah para pemain harus bisa menari, ngidung, mengetahui irama gending atau gamelan (Darmawan \& Wahyurini, 2016).

Bentuk kesenian Besutan berubah menjadi kesenian Ludruk dengan bentuk pementasan sandiwara dengan tokoh yang semakin bertambah jumlahnya. Bentuk ini tetap mempertahankan ciri khas Besutan seperti tarian ngremo, kidungan, dagelan, dan cerita (lakon). Inilah yang mendasari bahwa cikal bakal Kesenian Ludruk berasal dari Kesenian Besutan (Damayanti, 2007).

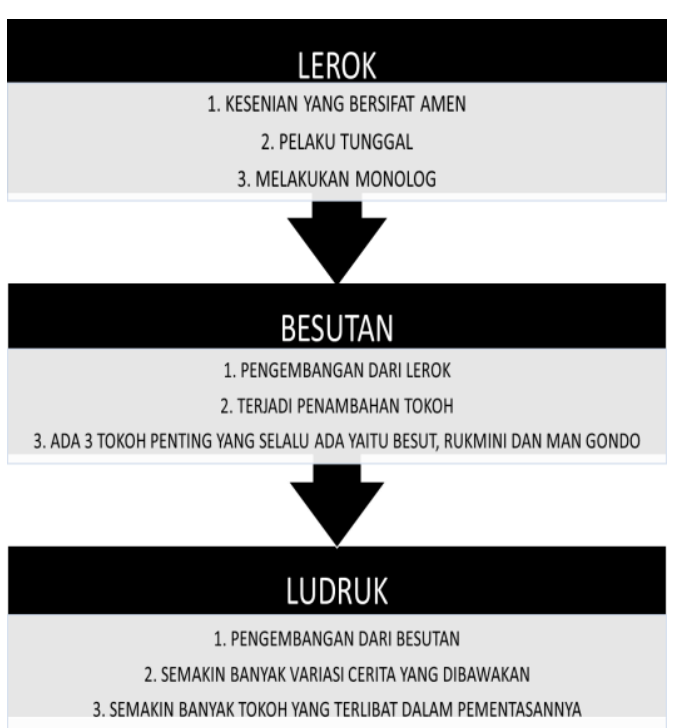

Gambar 1. Alur Perkembangan Lerok -

Besutan - Ludruk

\section{Bentuk Penyajian Kesenian Besutan}

Ada beberapa unsur pendukung dalam pelaksanaan kesenian Besutan mulai dari tempat pertunjukan, tata rias para pemain, tata busana atau kostum para 
pemain, alat musik penggiring, dan urutan pementasan dalam kesenian Besutan.

Tatanan Panggung Kesenian Besutan Umumnya pementasan teater rakyat meskipun jenisnya berbeda tetapi cara pementasannya sama. Kesenian tradisional yang berasal dari timur tidak mengenal adanya panggung, bisa dilakukan di mana saja asalkan ada tempat lapang. Bersumber dari bentuk dan sifat dari kesenian Besutan yang sederhana dan spontan, tempat pertunjukan kesenian Besutan dapat dipentaskan di mana saja asalkan di alam terbuka, ada arena untuk melakukan kesenian Besutan, dan ada tempat untuk para penonton (Anggita, 2013). Karena awal kesenian Besutan adalah kesenian amen yang tidak memerlukan banyak tempat, saat Besutan menjadi kesenian yang diundang pun tidak memerlukan banyak persiapan untuk tempat pertunjukannya.

Tata panggung merupakan sesuatu yang harus dipersiapkan dalam pementasan yang berhubungan dengan tempat pelaksanaan kesenian Besutan. Perlengkapan yang digunakan sangat sederhana, disesuaikan dengan keadaan setempat atau sesuai dengan naskah cerita yang akan ditampilkan. Syarat paling penting dalam menyiapkan tatanan pertunjukan kesenian Besutan adalah tidak adanya batas antara pemain dan penonton agar para pemain bisa berinteraksi dengan para penonton. Interaksi yang dijalin oleh pemain dan penonton bisa menciptakan dialog guyonon (lelucon) dan sindiransindiran baik oleh pemain ataupun oleh penonton (Damayanti, 2007). Penggunaan panggung dalam kesenian Besutan apabila kesenian Besutan dipentaskan atau dilombakan. Namun, seiring berjalannya waktu, kesenian Besutan bisa ditampilkan di atas panggung sesuai dengan permintaan pengundang. Tatanan panggung seperti terlihat pada Gambar 2.

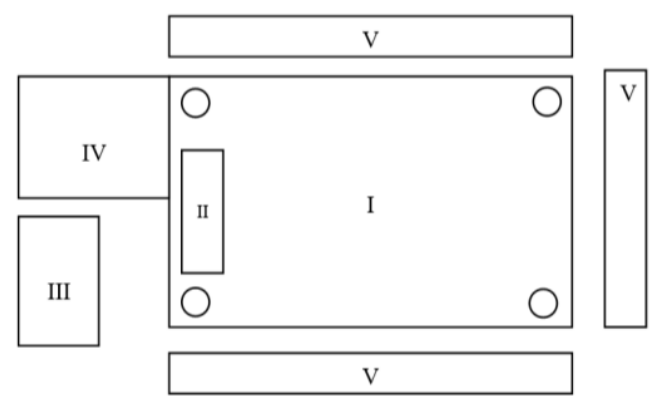

Gambar 2. Tatanan Panggung Kesenian Besutan

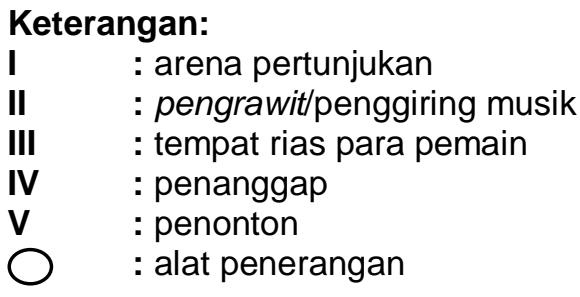

Tata Rias Para Pemain Besutan

Tata rias yang ada dalam pertunjukan seni tradisional digunakan untuk menonjolkan karakter pemain pertunjukan. Dalam kesenian Besutan tata rias yang digunakan cukup sederhana namun dapat menonjolkan karakter para pemainnya. Di mulai dari pemeran Besut, pada awal kemunculannya Besut merias wajahnya dengan bedak putih tebal seperti topeng. Warna putih di dapat dari bedak atau lulur yang berasal dari beras yang sudah dihaluskan dan diberi air kemudian di oleskan ke wajah, dan kemudian di bagian alis dipertebal (Damayanti, 2007). Seiring berjalannya waktu tata rias Besut berubah, wajahnya diperlihatkan tanpa bedak putih tebal dan alis tebal. Hal ini dilakukan karena pada zaman dahulu Besut muncul dengan penyampaian wajah yang di coret-coret agar tampak lucu. Namun saat ini wajah Besut tanpa bedak tebal dan alis tebal, ini menggambarkan Besut sebagi pemuda Indonesia yang gagah dan tampan

Tokoh Man Gondo pada awal kemunculannya menggunakan tata rias bedak tipis bertolak belakang dengan Besut, namun seiring perkembangan Besutan tata rias Man Gondo berubah. Perubahan ini terjadi karena anggapan Man Gondo adalah tokoh antagonis sehingga riasannya diubah. Man Gondo berwajah putih tebal menggambarkan dia adalah orang pribumi yang berkhianat kepada penjajah yang selama ini memakai topeng (Rifanti, 2017). Topeng merupakan manifestasi dari seseorang yang memiliki sifat munafik, dan tokoh Man Gondo digambarkan sebagai seseorang yang munafik.

Tata rias pada tokoh Rusmini adalah wanita cantik, namun ada perbedaan dari awal kemunculan hingga perkembangannya. Pada awal kemunculan tokoh Rusmini diperankan oleh laki-laki sehingga tata rias yang digunakan harus secantik dan setebal mungkin seperti wanita pada umumnya. Namun setelah tokoh Rusmini diperankan oleh perempuan maka riasan yang digunakan oleh Rusmini tidak setebal dahulu (Anggita, 2013). Untuk 
perkembangannya tokoh Rusmini memakai tata rias tipis namun tetap menonjolkan kecantikannya, Rusmini digambarkan sebagai wanita yang sederhana namun tegas. Untuk penggambaran tokoh yang lain disesuaikan dengan naskah dan karakter yang akan mereka tampilkan.

\section{Tata Busana atau Kostum Para Pemain Besutan}

Pakaian pentas atau kostum adalah pakaian dan perlengkapan yang digunakan oleh seorang pemain dalam sebuah pementasan. Kostum terdiri dari pakaian yang biasa digunakan oleh para pemain untuk mendukung cerita yang akan dibawakan. Kostum digunakan dengan tujuan agar penonton dapat melihat karakter dari para pemain dan membantu memperlihatkan apa yang ingin disampaikan pemain kepada penonton (Damayanti, 2007). Selain diperlukan penghayatan jiwa, pakaian juga sangat diperlukan untuk menyampaikan atau mengomunikasikan makna lakon yang ditampilkan.

Pakaian atau kostum yang digunakan oleh kesenian Besutan dijelaskan bahwa hanya kostum Besut saja yang mempunyai pakaian pakem, pakaian pemain lain disesuaikan dengan cerita yang ingin disampaikan. Kostum yang digunakan oleh Besut dalam setiap kesenian Besutan adalah bebet atau kain putih yang dililit, memakai celana hitam, sampur atau selendang merah, topi Turki merah, dan tali lawe yang di ikat di pinggangnya (Anggita, 2013). Setiap pakaian memiliki makna tersendiri, begitu juga penggunaan warna pakaian yang digunakan.

Simbol dan makna warna busana Besut yang pertama adalah warna merah melambangkan keberanian yaitu berani karena benar, sedangkan warna putih simbol suci yaitu suci dalam niat, dan warna hitam simbol ketegasan yaitu tegas dalam tindakan. Simbol dan makna busana pokok dan pelengkap Besutan yang pertama adalah Bebet simbol pelindung raga yaitu melindungi badan, celana sebagai simbol energik artinya aktif dalam tindakan, kemudian topi sebagai simbol pelindung pustaka artinya melindungi akal pikiran, sampur sebagai simbol kesempurnaan artinya kesempurnaan adalah tujuan, dan terakhir tali lawe simbol persatuan artinya persatuan kembali merebut kemerdekaan (Putri, 2016). Pakaian yang digunakan Besut menggambarkan sifat Besut dan juga memiliki maksud tertentu yang ingin disampaikan kepada penonton agar dapat memahami cerita.

\section{Alat Musik Penggiring dalam Kesenian Besutan}

Musik penggiring dalam suatu kesenian di anggap sebagai pendukung kesenian yang berperan penting untuk membawa suasana agar para penonton lebih menikmati alur cerita yang disampaikan oleh para pemain. Bentuk awal iringan musik dalam kesenian Besutan hanya menggunakan mulut, dilanjutkan dengan membawa satu alat musik yaitu kempul (Anggita, 2013). Besutan yang awalnya berkeliling dari rumah ke rumah hanya dengan membawa satu alat musik sebagai penggiring kini mulai berkembang dengan menambah alat musik penggiringnya. Seiring berjalannya waktu dan kesenian Besutan yang sudah menjadi kesenian yang diundang dan sudah disempurnakan, alat musik penggiring dalam kesenian Besutan juga disempurnakan menjadi gamelan Jawa lengkap berlaras slendro.

\section{Urutan Pementasan dalam Kesenian Besutan}

Urutan pementasan adalah jalannya pertunjukan mulai dari awal sampai selesai. Pada kesenian Besutan tidak mempunyai urutan yang pakem, namun tata urutan yang lebih sering dipakai adalah tata urutan yang saat ini sering di pertunjukan dalam kesenian Besutan. Tata urutan penampilan kesenian Besutan selalu diawali dengan semacam ritual yang yang berfungsi sebagai pembuka (Nasrulloh, 2011). Ritual dilakukan untuk menghormati pengundang dan penonton kesenian Besutan. Ritual yang dilakukan adalah dengan menyembah empat arah mata angin Setelah ritual dilakukan maka pertunjukan Kesenian Besutan dimulai.

Pada awal pertunjukan Besutan, Pembawa Obor masuk ke tengah arena diikuti Besut yang masuk ke arena dengan cara ngesot atau berjalan sambil duduk dengan keadaan mata tertutup dan mulut tersumpal oleh susur. Besut mulai meraba letak obor dan mematikan obor dengan susur yang diambil dalam mulutnya. Hal ini menggambarkan seseorang yang ingin bangkit dari keterpurukan, api diartikan sebagai permasalahan yang harus dipadamkan atau diselesaikan. Setelah 
obor padam Besut membuka penutup dan mulai menari-nari. Tarian yang dilakukan oleh Besut adalah tari remo, tarian ini menggambarkan kesenangan Besut karena telah berhasil memadamkan obor. Kemudian acara berlanjut dengan kidungan, yaitu nyanyian yang mengandung pesan baik pesan ajakan atau pesan larangan. Kidungan dilakukan sahutsahutan antara pemain, pemain dengan pengrawit atau penggiring musik, dan juga antara pemain dengan penonton, dilanjutkan dengan kidungan jula-juli. Setelah semua rangkaian acara sudah dilakukan maka pertunjukan terakhir adalah masuk ke dalam cerita. Cerita yang disajikan dalam kesenian Besutan disesuaikan dengan tema acara atau sesuai dengan permintaan pengundang (Damayanti, 2007). Tema cerita dalam kesenian Besutan mengambil dari kisah sehari-hari masyarakat. Jika cerita sudah selesai maka selesai pula pertunjukan kesenian Besutan. Besutan tidak memiliki urutan tampil yang pakem namun urutan tampil yang sering dilakukan yaitu ritual, pembawa obor dan Besut yang memasuki arena pertunjukan, menari, kidungan, dan masuk ke dalam cerita yang akan ditampilkan.

\section{Upaya Pelaku Seni Dan Pemerintah Kabupaten Jombang Dalam Mempertahankan Kesenian Besutan Agar Tetap Eksis Di Era Saat Ini

Kesenian Besutan tengah

mengalami permasalahan yang sama dengan kesenian atau kebudayaan daerah lain yang ada di Indonesia, yaitu kesenian ini mulai punah akibat tidak adanya generasi penerus dan tergerus oleh arus perkembangan zaman yang semakin modern (Rifanti, 2017). Proses regenerasi yang tidak berjalan dalam hal pelaku seni di Jombang menjadi salah satu penyebab kurangnya minat pada kesenian tradisional khususnya Besutan (Firmansyah, 2015). Pelaku seni yang bergerak dalam bidang ini juga semakin berkurang, tercatat jumlah pelaku seni di Jombang semakin berkurang dihitung mulai tahun 2008 (RPJMD Kabupaten Jombang, 2019). Pemerintah Kabupaten Jombang menginginkan kembalinya kesenian Besutan untuk dinikmati kembali oleh masyarakat Kabupaten Jombang. Upaya-uapa dalam rangka mempertahankan Kesenian Besutan dari pemerintah dan pelaku seni sepertit terlihat pada Tabel 1.
Tabel 1. Upaya Mempertahankan Kesenian Besutan

\begin{tabular}{|l|l|}
\hline Upaya Pemerintah & Upaya Pelaku Seni \\
\hline $\begin{array}{l}\text { 1. Membentuk Dewan } \\
\text { Kesenian yang } \\
\text { digunakan sebagai } \\
\text { wadah bagi semua } \\
\text { kesenian tradisional } \\
\text { milik Kabupaten }\end{array}$ & $\begin{array}{l}\text { 1. Menampilkan } \\
\text { kesenian Besutan } \\
\text { dengan konsep } \\
\text { lebih modern namun } \\
\text { tidak meninggalkan } \\
\text { unsur tradisionalnya }\end{array}$ \\
\hline $\begin{array}{l}\text { 2. Memasukkan materi } \\
\text { Besutan ke dalam } \\
\text { kurikulum Seni Budaya } \\
\text { (muatan lokal) sekolah } \\
\text { menengah di Jombang }\end{array}$ & $\begin{array}{l}\text { 2. Membentuk suatu } \\
\text { wadah agar } \\
\text { kesenian Besutan } \\
\text { ini bisa } \\
\text { diperkenalkan } \\
\text { kepada masyarakat } \\
\text { dan bahkan kepada } \\
\text { generasi muda } \\
\text { kesenian Besutan } \\
\text { sebagai Aset Budaya } \\
\text { milik Kabupaten }\end{array}$ \\
Jombang & \\
\hline
\end{tabular}

Pemerintah Kabupaten Jombang sudah berusaha menggiatkan kembali kesenian ini dengan membentuk dewan kesenian yang digunakan sebagai wadah bagi semua kesenian tradisional milik Kabupaten Jombang agar lebih diperhatikan dan dilestarikan keberadaannya. Pemerintah Kabupaten Jombang juga telah mendaftarkan kesenian Besutan sebagai Aset Budaya tak Benda milik Kabupaten Jombang agar upaya dalam pelestarian kesenian Besutan lebih maksimal (Supriadi, 2012). Dengan mendaftarkan kesenian Besutan ke dalam aset budaya tak benda yang harus dilindungi membuat kesenian Besutan mendapat perhatian yang lebih dari pemerintah. Pemerintah Kabupaten Jombang juga mengupayakan kelestarian kesenian Besutan ini dengan memasukkan materi Besutan ke dalam kurikulum Seni Budaya (muatan lokal) sekolah menengah di Jombang (Darmawan \& Wahyurini, 2016). Namun dalam pelaksanaannya masih perlu pengkajian lebih dalam lagi, karena minimnya sumber dan materi Besutan yang tersedia

Upaya yang dilakukan oleh pemerintah tidak akan cukup dalam mempertahankan kesenian Besutan di Kabupaten Jombang. Oleh karena itu perlu upaya dari pelaku seni di Kabupaten Jombang untuk ikut serta dalam melestarikan dan menjaga kesenian Besutan. Upaya yang saat ini dilakukan oleh pelaku seni yaitu, menampilkan kesenian Besutan dengan konsep lebih modern namun tidak meninggalkan unsur tradisionalnya agar bisa dinikmati oleh generasi muda (Anggita, 2013). 
Tak hanya itu, pelaku seni juga membentuk suatu wadah agar kesenian Besutan ini bisa diperkenalkan kepada masyarakat dan bahkan kepada generasi muda, salah satu wadah yang mereka bentuk yaitu Sanggar Komunitas Tombo Ati. Dengan adanya komunitas ini pelaku seni bisa menampilkan kesenian Besutan dalam beberapa acara yang bisa digunakan sebagai upaya memperkenalkan kesenian Besutan dan untuk menarik minat para generasi muda untuk bergabung melestarikan kesenian Besutan (Damayanti, 2007). Usaha melestarikan dan menjaga kesenian Besutan merupakan usaha yang cukup sulit oleh karena dibutuhkan kerja sama dan tanggung jawab bersama dari pemerintah, pelaku seni, serta masyarakat agar usaha mempertahankan dan melestarikan kesenian Besutan bisa berjalan dengan baik.

\section{Pertimbangan Mengundang Kesenian Besutan}

Masyarakat pada umumnya akan mengundang sebuah hiburan jika mereka mengadakan hajatan, baik itu hajatan khitanan, perkawinan, nadzar atau punya janji, syukuran, pesta-pesta desa. Kesenian tradisional adalah hiburan yang paling sering di undang. Kesenian Besutan termasuk salah satu kesenian tradisional yang di undang oleh masyarakat sebagai hiburan di acara hajatan (Damayanti, 2007). Seperti tradisi yang selalu dilakukan, mengundang kesenian tradisional untuk memeriahkan hajatan sudah seperti tradisi yang selalu dilakukan oleh masyarakat terutama masyarakat Jawa. Namun dalam menentukan kesenian tradisional yang akan diundang merupakan tindakan yang penuh pertimbangan, karena kesenian tradisional di Kabupaten Jombang cukup banyak.

Banyaknya pilihan yang tersedia membuat masyarakat harus menentukan pilihannya dengan berbagai pertimbangan. Rasionalitas muncul ketika dihadapkan dengan banyaknya suatu pilihan-pilihan yang ada di depan mata, yang memberi kebebasan untuk menentukan pilihan, dan menuntut adanya satu pilihan yang harus ditentukan. Suatu pilihan dikatakan rasional bila pilihan tersebut diambil dengan maksud tertentu untuk memaksimalkan kebutuhannya. Pilihan rasional yang diambil akan menghasilkan konsekuensi tertentu berupa sikap maupun tindakan (Mafis, 2016).

Menurut para pengundang, ada beberapa alasan mengapa kesenian Besutan menjadi kesenian yang diundang sebagai hiburan saat masyarakat memiliki hajatan. Alasan pertama yaitu, kesenian Besutan merupakan kesenian asli Kabupaten Jombang yang sudah ada sejak zaman dahulu dan banyak masyarakat sudah mengetahui tentang kesenian ini sehingga akan lebih banyak orang yang menonton. Alasan ini termasuk dalam decision value yaiyu pilihan yang berkaitan dengan harapan secara umum mengenai daya tarik atau daya tolak pada suatu objek pilihan (Kahneman \& Travesky, 1984). Kedua, kesenian Besutan cukup sederhana dalam persiapannya ataupun alat-alat pendukungnya sehingga tidak akan rumit dalam mengundang kesenian Besutan. Ketiga, biaya mengundang kesenian Besutan cukup terjangkau dengan kualitas pertunjukan yang tak kalah bagus dengan kesenian tradisional lain. Beberapa alasan inilah yang membuat masyarakat mengundang kesenian Besutan (Anggita, 2013). Alasan keempat adalah penyesuaian naskah atau alur cerita dalam pertunjukan seni Besutan, naskah atau alur cerita dalam kesenian Besutan disesuaikan dengan tema acara yang mengundang kesenian Besutan atau juga bisa disesuaikan dengan permintaan pengundang. Masyarakat akan cenderung memilih mengundang kesenian yang cukup sederhana mengingat kesenian tradisional memiliki persiapan yang cukup rumit dengan adanya ritual-ritual. Selain itu biaya juga mempengaruhi masyarakat dalam mengundang sebuah kesenian tradisional. Alasan ketiga dan keempat termasuk pilihan yang dipengaruhi oleh experience value yaitu pilihan yang terkait dengan kenikmatan atau kepedihan, kepuasan atau kekecewaan pada suatu objek pilihannya (Kahneman \& Travesky, 1984).

Berbagai macam pilihan inilah yang membuat manusia membutuhkan suatu tindakan. Tindakan-tindakan sosial ini membawa manusia dalam suatu pilihan untuk menentukan jalan hidupnya (Johnson, 1988). Banyaknya faktor penentu dalam pilihan yang akan diambil oleh individu menjadikan pilihan yang akan diambil menjadi sangat berkesan (Mafis, 2016). Menjadikan Besutan sebagai salah satu pilihan kesenian tradisional yang diundang dari sekian banyak kesenian 
tradisional yang ada di Kabupaten Jombang membuat kesenian Besutan ini pantas untuk dipertahankan keberadaannya.

Kesenian Besutan adalah kesenian yang mengambil cerita dari kehidupan sehari-hari, menyajikan cerita yang menarik dan tidak lupa menyampaikan pesan di akhir pertunjukan membuat kesenian Besutan menarik untuk ditonton. Tak hanya itu, dalam pementasan kesenian Besutan para pemain selalu berinteraksi dengan penonton dan menjadikan kesenian ini lebih menarik (Nasrulloh, 2011). Kesenian Besutan diterima keberadaannya sebagai suatu kesenian tradisional yang menghibur masyarakat, hal ini mengharuskan kesenian Besutan agar tetap ada sehingga masyarakat masih bisa menikmati kesenian ini hingga sekarang.

Tabel 2. Pertimbangan Masyarakat Menggundang Besutan

\begin{tabular}{|c|c|c|}
\hline No & Aspek & Pertimbangan \\
\hline 1. & $\begin{array}{l}\text { Biaya mengundang } \\
\text { kesenian Besutan } \\
\text { cukup terjangkau } \\
\text { dengan kualitas } \\
\text { pertunjukan yang tak } \\
\text { kalah bagus dengan } \\
\text { kesenian tradisional lain }\end{array}$ & $\begin{array}{l}\text { Alasan utama } \\
\text { menggundang } \\
\text { Besutan }\end{array}$ \\
\hline 2. & $\begin{array}{l}\text { Kesenian Besutan } \\
\text { merupakan kesenian } \\
\text { asli Kabupaten } \\
\text { Jombang yang sudah } \\
\text { ada sejak zaman } \\
\text { dahulu dan banyak } \\
\text { masyarakat sudah } \\
\text { mengetahui tentang } \\
\text { kesenian ini }\end{array}$ & $\begin{array}{l}\text { Alasan } \\
\text { pendukung } \\
\text { menggundang } \\
\text { Besutan }\end{array}$ \\
\hline 3. & $\begin{array}{l}\text { Kesenian Besutan } \\
\text { cukup sederhana dalam } \\
\text { persiapannya ataupun } \\
\text { alat-alat pendukungnya } \\
\text { sehingga tidak akan } \\
\text { rumit dalam } \\
\text { mengundang kesenian } \\
\text { Besutan }\end{array}$ & $\begin{array}{l}\text { Alasan lain } \\
\text { menggundang } \\
\text { Besutan }\end{array}$ \\
\hline
\end{tabular}

\section{SIMPULAN DAN SARAN}

Berdasarkan hasil dari penelitian diketahui bahwa Besutan adalah kesenian teater rakyat yang menceritakan tentang kehidupan sehari-hari masyarakatnya dan terus berkembang seiring dengan perkembangan masyarakatnya. Awal kemunculan kesenian Besutan yaitu pada tahun 1907. Besutan merupakan kesenian yang berkembang dari kesenian Lerok dan merupakan cikal bakal dari kesenian Ludruk. Hingga perkembangannya saat ini kesenian Besutan menjadi identitas budaya Kabupaten Jombang.

Unsur pendukung dalam pementasan kesenian Besutan adalah iringan musik, tata rias, dan kostum yang sederhana. Pada awal kemunculannya penyajian kesenian Besutan sangat sederhana, namun seiring berjalannya waktu penyajian kesenian Besutan semakin disempurnakan. Dalam penyajiannya kesenian Besutan dimulai dengan ritual pembuka. Ritual yang dilakukan adalah menyembah empat arah mata angin. Setelah ritual sudah dilaksanakan maka pertunjukan seni Besutan dimulai, orang pertama yang masuk ke arena adalah pembawa obor, dilanjut Besut memasuki arena dan mulai menari, kidungan, dan masuk ke dalam cerita hingga cerita selesai.

Pemerintah telah mengupayakan agar kesenian Besutan ini tetap ada dan dilestarikan, salah satunya dengan mendirikan dewan kesenian di Kabupaten Jombang. Pemerintah juga telah mendaftarkan kesenian Besutan sebagai aset budaya milik Kabupaten Jombang. Selain pemerintah, para pelaku seni yang ada di Jombang juga berupaya agar kesenian Besutan ini tetap eksis di era saat ini yaitu dengan menampilkan Besutan dalam tampilan yang lebih modern agar bisa dinikmati oleh generasi muda. Tak hanya itu, pelaku seni juga mulai memperkenalkan Besutan dalam ekstrakulikuler teater sekolah sehingga para generasi muda bisa mengenal kesenian Besutan dan mulai melestarikan kesenian Besutan.

Kesenian Besutan masih memiliki tempat tersendiri di hati masyarakat. Banyak dari mereka masih menginginkan mengundang kesenian Besutan sebagai hiburan dikala mereka mengadakan hajatan. Pertimbangan mereka masih mengundang kesenian Besutan karena kesenian Besutan mengambil cerita dari kehidupan sehari-hari masyarakat. Kesenian Besutan dikemas secara sederhana sehingga cerita dan pesan dalam cerita bisa tersampaikan. Biaya mengundang kesenian Besutan relatif terjangkau dengan kualitas yang bagus, naskah atau cerita yang akan ditampilkan disesuaikan dengan permintaan pengundang atau disesuaikan dengan tema acara, dan kesenian Besutan lebih sederhana dari pada kesenian tradisional yang lain. 


\section{DAFTAR PUSTAKA}

Anggita, L. M. (2013). Revitalisasi Kesenian Besutan di Kabupaten Jombang (1980-2012). Malang: Universitas Negeri Malang.

Arifninetrirosa. (2005). Pemeliharaan Budaya Kehidupan Tradisional Dalam Pembangunan Nasional. Medan: Universitas Sumatra Utara. Retrieved from

http//repository.usu.ac.id/bitsream/123 456789/1675///etnomusikologiarifni5.p df

Bungin, B. (2017). Penelitian Kualitatif: Komunikasi, Ekonomi, Kebijakan Publik, dan IImu Sosial Lainnya. Sidoarjo: Kencana.

Damayanti. (2007). Besutan (Kajian Etnografi Besutan Sebagai Cikal Bakal Ludruk di Kabupaten Jombang). Surabaya: Universitas Airlangga Surabaya. Retrieved from http://repository.unair.ac.id/17395/

Darmawan, Y. S., \& Wahyurini, O. D. (2016). Perancangan Film Dokumenter Besutan sebagai Media Pendidikan Remaja Usia 12-18 tahun. Surabaya: Institut Teknologi Sepuluh Nopember. Retrieved from Dari https://caridokumen.com/queue/peranc angan-filmdokumenter-kesenianbesutan-asal-jombang-

5a46d45fb7d7bc7b7a21c8de_pdf?qu eue_id=-1.

Firmansyah. (2015). Perancangan Pusat Edukasi dan Rekreasi Budaya Jombang di Jombang. Malang: Universitas Islam Negeri Malang. Retrieved from http://etheses.uinmalang.ac.id/3637/1/10660005.pdf

Indarti, Y. (2008). Metafora dalam Ludruk. Yogyakarta: Univeristas Gadjah Mada.

Irianto. (2009). Metodologi Penelitian Kualitatif: Aplikasi untuk penelitian pendidikan, hukum, ekonomi dan manajemen, sosial, humaniora, politik, agama dan filsafat. Jakarta: Gaung Persada Press.

Irianto, \& Subandi. (2015). Studi Fenomenologis Kebahagiaan Guru di Papua. Gadjah Mada Journal of Psychology, 1(3).

Johnson, D. P. (1988). Teori Sosial Modern dan Klasik. Jakarta: Pt. Gramedia Pustaka Utama.

Kahneman, D., \& Travesky. (1984). Choices, Values, and Frames. American Psychologist, 39(4).
Mafis, S. E. (2016). Teori Pilihan Rasional. Jakarta: Universitas Muhamadiyah Prof. Dr. Hamka.

Mujib, A. (2015). Pendektan Fenomenologi dalam Studi Islam. Al-Tadzkiyyah: Jurnal Pendidikan Islam, 6.

Nasrulloh, F. (2011). Melacak Ludruk Jombang. Jombang: Badan Perencanaan Pembangunan.

Pamungkas. (2016). Ludruk Karya Budaya Di Tengah Hiruk Pikuk Perubahan. Universitas Islam Negeri Surabaya. Surabaya: Eprint Universitas Islam Negeri Surabaya. Retrieved from http://digilib.uinsby.ac.id/id/eprint/6292

Putri, D. A. (2016). Modifikasi Busana Besutan. Surabaya: Universitas Negeri Surabaya.

Raharjo. (2006). Pendhalungan: Sebuah "Periuk Besar" Masyarakat Multikultural. Yogyakarta.

Rifanti. (2017). Penanaman Nilai-Nilai Kearifan Lokal Melalui Pementasan Drama tradisional besutan di Kabupaten Jombang. Malang: Universitas Negeri Malang.

RPJMD Kabupaten Jombang. (2019). Rencana Pembangunan Jangka Menengah Daerah Kabupaten Jombang Tahun 2018-2023. Jombang: Kabupaten Jombang. Retrieved from https://jdih.jombangkab.go.id/download /2019_perda/PERDA-1-TH-2019-BabI-II.pdf

Rustanto, B. (2015). Penelitian kualitatif pekerjaan sosial. Bandung: Rosda Karya.

Septiyan, D. D. (2016). Eksistensi Kesenian Gambang Semarang Dalam Budaya Semarang. Jurnal Pendidikan dan Kajian Seni.

Sugiyono. (2016). Memahami Penelitian Kualitati. Bandung: CV Alfabeta.

Supriadi. (2012). Regenerasi Reog Ponorogo Untuk Mendukung Revitalisasi seni Pertunjukan Tradisional Dan Menunjang Pembangunan Industri Kreatif.

Supriadi. (2015). Regenerasi Seniman Reog Ponorogo Untuk Mendukung Revitalisasi Seni Pertunjukan Tradisional dan Menunjang Pembanggunan Industri Kreatif. Jurnal Pariwisata dan Budaya, 16(1). 